\title{
1 Gut-brain axis: A matter of concern in neuropsychiatric disorders...!
}

2 Muhammad Naveed ${ }^{a}$, Qi-Gang Zhou', Liandi Lib, Abdoh Taleb ${ }^{\mathrm{a}}$, Meng Fan ${ }^{\mathrm{a}}$, Bilal

3 Ahmed ${ }^{\mathrm{a}}$, Yu Zhang ${ }^{\mathrm{a}}$, Fatima Majeed ${ }^{\mathrm{c}}$, Yingmei Lu', Feng Han ${ }^{\mathrm{a}}$ *

$4{ }^{a}$ Key Laboratory of Cardiovascular and Cerebrovascular Medicine, School of Pharmacy,

5 Nanjing Medical University, Jiangsu Province, Nanjing 211166, P.R China

$6{ }^{b}$ Department of Clinical Pharmacology, School of Pharmacy, Nanjing Medical University,

7 Jiangsu Province, Nanjing 211166, P.R China

$8{ }^{c}$ Department of Nutrition and Food Hygiene, School of Public Health, Nanjing Medical

9 University, Jiangsu Province, Nanjing 211166, P.R China

10 Correspondence: Feng Han, Key Laboratory of Cardiovascular and Cerebrovascular Medicine,

11 School of Pharmacy, Nanjing Medical University, Jiangsu Province, Nanjing 211166, P.R China,

12 E-mail: fenghan169@njmu.edu.cn.

\section{Abstract}

14 The gut microbiota is composed of a large number of microbes, usually regarded as commensal

15 bacteria. It has become gradually clear that gastrointestinal microbiota affects not only gut

16 pathophysiology but also the central nervous system (CNS) function by modulating the signaling

17 pathways of the gut-microbiota-brain axis. This bidirectional gut-microbiota-brain axis

18 communication primarily acts through neuroendocrine, neuroimmune, and autonomic nervous

19 systems (ANS) mechanisms. Accumulating evidence reveals that gastrointestinal microbiota

20 interacts with the host brain, and its modulation may play a critical role in the pathology of

21 neuropsychiatric disorders. Recently, neuroscience research has established the significance of 
22 gut microbiota in the development of brain systems that are essential to stress-related behaviors,

23 including depression and anxiety. Application of modulators of the microbiota-gut-brain axis,

24 such as psychobiotics (e.g., probiotics), prebiotics, and specific diets, may be a promising

25 therapeutic strategy for neuropsychiatric disorders. The presented review article primarily

26 focuses on the relevant features of the disturbances of the gut-microbiota-brain axis in the

27 pathophysiology of neuropsychiatric disorders and its potential therapeutic target in

28 neuropsychiatric disorders, including depression and anxiety.

29 Keywords: Gut microbiota; Gut-brain axis; Neuroimmune; HPA axis; Vagus nerve; Psychiatric

30 disorders; Depression; Cognitive function; Psychobiotics;

31 Acknowledgments

32 This work was supported by the National Natural Science Foundations of China (grant 81573411

33 to F.H) PR China. Furthermore, the lead author (Naveed M.,) is profoundly grateful to beloved

34 Co-supervisor Prof. Dr. Qi-Gang Zhou for his an elicited idea to write this reappraisal.

35 Conflict of interest

36 All authors declare no conflict of interest.

37 References

Aatsinki A-K, Lahti L, Uusitupa H-M, Munukka E, Keskitalo A, Nolvi S, et al. Gut microbiota composition is associated with temperament traits in infants. Brain, Behavior, and Immunity. 2019;80:849-58. Achtyes E, Keaton SA, Smart L, Burmeister AR, Heilman PL, Krzyzanowski S, et al. Inflammation and kynurenine pathway dysregulation in post-partum women with severe and suicidal depression. Brain, 42 Behavior, and Immunity. 2020;83:239-47.

43 Ait-Belgnaoui A, Durand H, Cartier C, Chaumaz G, Eutamene H, Ferrier L, et al. Prevention of gut 44 leakiness by a probiotic treatment leads to attenuated HPA response to an acute psychological stress in 45 rats. Psychoneuroendocrinology. 2012;37:1885-95. 
Al Omran Y, Aziz Q. The Brain-Gut Axis in Health and Disease. In: Lyte M, Cryan JF, editors. Microbial Endocrinology: The Microbiota-Gut-Brain Axis in Health and Disease. New York, NY: Springer New York; 2014. p. 135-53. Antushevich H. Fecal microbiota transplantation in disease therapy. Clinica Chimica Acta. 2020;503:90-8. Appleton J. The Gut-Brain Axis: Influence of Microbiota on Mood and Mental Health. Integr Med (Encinitas). 2018;17:28-32.

Arentsen T, Qian Y, Gkotzis S, Femenia T, Wang T, Udekwu K, et al. The bacterial peptidoglycan-sensing molecule Pglyrp2 modulates brain development and behavior. Molecular Psychiatry. 2017;22:257-66.

Arentsen T, Raith H, Qian Y, Forssberg H, Diaz Heijtz R. Host microbiota modulates development of social preference in mice. Microb Ecol Health Dis. 2015;26:29719-.

Arseneault-Bréard J, Rondeau I, Gilbert K, Girard S-A, Tompkins TA, Godbout R, et al. Combination of Lactobacillus helveticus R0052 and Bifidobacterium longum R0175 reduces post-myocardial infarction depression symptoms and restores intestinal permeability in a rat model. British Journal of Nutrition. 2011;107:1793-9. doxycycline. Molecular Psychiatry. 2018;23:1584-9.

Bastiaanssen T, Cussotto S, Claesson M, Clarke G, Dinan T, Cryan J. Gutted! Unraveling the Role of the Microbiome in Major Depressive Disorder. Harvard Review of Psychiatry. 2020;28:26-39.

Belkaid Y, Hand TW. Role of the microbiota in immunity and inflammation. Cell. 2014;157:121-41.

Bercik P, Park AJ, Sinclair D, Khoshdel A, Lu J, Huang X, et al. The anxiolytic effect of Bifidobacterium longum NCC3001 involves vagal pathways for gut-brain communication. Neurogastroenterol Motil. 2011;23:1132-9.

Bercik P, Verdu EF, Foster JA, Macri J, Potter M, Huang X, et al. Chronic gastrointestinal inflammation induces anxiety-like behavior and alters central nervous system biochemistry in mice. Gastroenterology. 2010;139:2102-12.e1.

Berk M, Williams L, Jacka FN, O'Neil A, Pasco JA, Moylan S, et al. So depression is an inflammatory disease, but where does the inflammation come from? BMC medicine. 2013;11:200.

Bliss ES, Whiteside E. The Gut-Brain Axis, the Human Gut Microbiota and Their Integration in the Development of Obesity. Frontiers in Physiology. 2018;9.

Blumberg R, Powrie F. Microbiota, disease, and back to health: a metastable journey. Science translational medicine. 2012;4:137rv7-rv7.

Bollinger JL, Bergeon Burns CM, Wellman CL. Differential effects of stress on microglial cell activation in male and female medial prefrontal cortex. Brain Behav Immun. 2016;52:88-97.

Borre YE, Moloney RD, Clarke G, Dinan TG, Cryan JF. The Impact of Microbiota on Brain and Behavior: Mechanisms \& Therapeutic Potential. In: Lyte M, Cryan JF, editors. Microbial Endocrinology: The Microbiota-Gut-Brain Axis in Health and Disease. New York, NY: Springer New York; 2014a. p. 373-403.

Borre YE, O'Keeffe GW, Clarke G, Stanton C, Dinan TG, Cryan JF. Microbiota and neurodevelopmental windows: implications for brain disorders. Trends in Molecular Medicine. 2014b;20:509-18.

Braniste V, Al-Asmakh M, Kowal C, Anuar F, Abbaspour A, Toth M, et al. The gut microbiota influences blood-brain barrier permeability in mice. Science translational medicine. 2014;6:263ra158.

Bravo JA, Forsythe P, Chew MV, Escaravage E, Savignac HM, Dinan TG, et al. Ingestion of Lactobacillus strain regulates emotional behavior and central GABA receptor expression in a mouse via the vagus nerve. Proceedings of the National Academy of Sciences of the United States of America. 2011;108:16050-5.

Browning KN, Travagli RA. Central nervous system control of gastrointestinal motility and secretion and modulation of gastrointestinal functions. Comprehensive Physiology. 2014;4:1339-68. 
Buffington SA, Di Prisco GV, Auchtung TA, Ajami NJ, Petrosino JF, Costa-Mattioli M. Microbial Reconstitution Reverses Maternal Diet-Induced Social and Synaptic Deficits in Offspring. Cell. 2016;165:1762-75.

Burokas A, Arboleya S, Moloney RD, Peterson VL, Murphy K, Clarke G, et al. Targeting the MicrobiotaGut-Brain Axis: Prebiotics Have Anxiolytic and Antidepressant-like Effects and Reverse the Impact of Chronic Stress in Mice. Biol Psychiatry. 2017a;82:472-87.

Burokas A, Arboleya S, Moloney RD, Peterson VL, Murphy K, Clarke G, et al. Targeting the MicrobiotaGut-Brain Axis: Prebiotics Have Anxiolytic and Antidepressant-like Effects and Reverse the Impact of Chronic Stress in Mice. Biological Psychiatry. 2017b;82:472-87.

Caracciolo B, Xu W, Collins S, Fratiglioni L. Cognitive decline, dietary factors and gut-brain interactions. Mechanisms of Ageing and Development. 2014;136-137:59-69.

Carr A. The handbook of child and adolescent clinical psychology: A contextual approach: Third edition2015.

Chassaing B, Koren O, Goodrich JK, Poole AC, Srinivasan S, Ley RE, et al. Dietary emulsifiers impact the mouse gut microbiota promoting colitis and metabolic syndrome. Nature. 2015;519:92-6.

Chu C, Murdock MH, Jing D, Won TH, Chung $H$, Kressel AM, et al. The microbiota regulate neuronal function and fear extinction learning. Nature. 2019;574:543-8.

Chung Y-C, Jin H-M, Cui Y, Kim D, Jung J, Park J-I, et al. Fermented milk of Lactobacillus helveticus IDCC3801 improves cognitive functioning during cognitive fatigue tests in healthy older adults. Journal of Functional Foods. 2014;10:465-74.

Clarke G, Cryan JF, Dinan TG, Quigley EM. Review article: probiotics for the treatment of irritable bowel syndrome - focus on lactic acid bacteria. Alimentary Pharmacology \& Therapeutics. 2012a;35:403-13.

Clarke G, Grenham S, Scully P, Fitzgerald P, Moloney R, Dinan TG, et al. The microbiome-gut-brain axis during early life regulates the hippocampal serotonergic system in a sex-dependent manner. Mol Psychiatry. 2012b;18.

Clarke G, Grenham S, Scully P, Fitzgerald P, Moloney RD, Shanahan F, et al. The microbiome-gut-brain axis during early life regulates the hippocampal serotonergic system in a sex-dependent manner. Molecular Psychiatry. 2013;18:666-73.

Collins SM, Bercik P. The relationship between intestinal microbiota and the central nervous system in normal gastrointestinal function and disease. Gastroenterology. 2009;136:2003-14.

Collins SM, Surette $M$, Bercik $P$. The interplay between the intestinal microbiota and the brain. Nature reviews Microbiology. 2012;10:735-42.

Cryan JF, Dinan TG. Mind-altering microorganisms: the impact of the gut microbiota on brain and behaviour. Nat Rev Neurosci. 2012;13:701-12.

Dalile B, Van Oudenhove L, Vervliet B, Verbeke K. The role of short-chain fatty acids in microbiota-gutbrain communication. Nature Reviews Gastroenterology \& Hepatology. 2019;16:461-78.

Davari S, Talaei SA, Alaei H, Salami M. Probiotics treatment improves diabetes-induced impairment of synaptic activity and cognitive function: behavioral and electrophysiological proofs for microbiome-gutbrain axis. Neuroscience. 2013;240:287-96.

De Palma G, Collins SM, Bercik P, Verdu EF. The microbiota-gut-brain axis in gastrointestinal disorders: stressed bugs, stressed brain or both? J Physiol. 2014;592:2989-97.

Desbonnet L, Clarke G, Shanahan F, Dinan TG, Cryan JF. Microbiota is essential for social development in the mouse. Molecular psychiatry. 2014;19:146-8.

Desbonnet L, Clarke G, Traplin A, O'Sullivan O, Crispie F, Moloney RD, et al. Gut microbiota depletion from early adolescence in mice: Implications for brain and behaviour. Brain Behav Immun. 2015a;48:165-73. 
Desbonnet L, Clarke G, Traplin A, O'Sullivan O, Crispie F, Moloney RD, et al. Gut microbiota depletion from early adolescence in mice: Implications for brain and behaviour. Brain, Behavior, and Immunity. 2015b;48:165-73.

141 Desbonnet L, Garrett L, Clarke G, Kiely B, Cryan JF, Dinan TG. Effects of the probiotic Bifidobacterium infantis in the maternal separation model of depression. Neuroscience. 2010;170:1179-88.

Di Mauro A, Neu J, Riezzo G, Raimondi F, Martinelli D, Francavilla R, et al. Gastrointestinal function development and microbiota. Italian journal of pediatrics. 2013;39:15.

Dinan TG, Cryan JF. Regulation of the stress response by the gut microbiota: implications for psychoneuroendocrinology. Psychoneuroendocrinology. 2012;37:1369-78.

Dinan TG, Cryan JF. Gut instincts: microbiota as a key regulator of brain development, ageing and neurodegeneration. 2017a;595:489-503.

Dinan TG, Cryan JF. The Microbiome-Gut-Brain Axis in Health and Disease. Gastroenterology clinics of North America. 2017b;46:77-89.

Dinan TG, Stanton C, Cryan JF. Psychobiotics: a novel class of psychotropic. Biological psychiatry. 2013;74:720-6.

Erny D, Hrabe de Angelis AL, Jaitin D, Wieghofer P, Staszewski O, David E, et al. Host microbiota constantly control maturation and function of microglia in the CNS. 2015;18:965-77.

Evans SJ, Bassis CM, Hein R, Assari S, Flowers SA, Kelly MB, et al. The gut microbiome composition associates with bipolar disorder and illness severity. Journal of psychiatric research. 2017;87:23-9.

Evrensel A, Ceylan ME. Fecal Microbiota Transplantation and Its Usage in Neuropsychiatric Disorders. Clinical psychopharmacology and neuroscience : the official scientific journal of the Korean College of Neuropsychopharmacology. 2016;14:231-7.

Filiano AJ, Gadani SP, Kipnis J. Interactions of innate and adaptive immunity in brain development and function. Brain Res. 2015;1617:18-27.

Foster JA, Rinaman L, Cryan JF. Stress \& the gut-brain axis: Regulation by the microbiome. Neurobiology of Stress. 2017;7:124-36.

Frank MG, Fonken LK, Dolzani SD, Annis JL, Siebler PH, Schmidt D, et al. Immunization with Mycobacterium vaccae induces an anti-inflammatory milieu in the CNS: Attenuation of stress-induced microglial priming, alarmins and anxiety-like behavior. Brain Behav Immun. 2018;73:352-63.

Frohlich EE, Farzi A, Mayerhofer R, Reichmann F, Jacan A, Wagner B, et al. Cognitive impairment by antibiotic-induced gut dysbiosis: Analysis of gut microbiota-brain communication. Brain Behav Immun. 2016;56:140-55.

Gárate I, García-Bueno B, Madrigal JLM, Caso JR, Alou L, Gómez-Lus ML, et al. Toll-like 4 receptor inhibitor TAK-242 decreases neuroinflammation in rat brain frontal cortex after stress. J Neuroinflammation. 2014;11:8-.

Gareau M. Microbiota-Gut-Brain Axis and Cognitive Function. Advances in experimental medicine and biology. 2014a;817:357-71.

Gareau MG. Microbiota-gut-brain axis and cognitive function. Advances in experimental medicine and biology. 2014b;817:357-71.

Gareau MG, Wine E, Rodrigues DM, Cho JH, Whary MT, Philpott DJ, et al. Bacterial infection causes stress-induced memory dysfunction in mice. Gut. 2011;60:307.

Girard S-A, Bah T, Kaloustian S, Lada-Moldovan L, Rondeau I, Tompkins T, et al. Lactobacillus helveticus and Bifidobacterium longum taken in combination reduce the apoptosis propensity in the limbic system after myocardial infarction in a rat model. The British journal of nutrition. 2009;102:1420-5.

Greenberg PE, Fournier AA, Sisitsky T, Pike CT, Kessler RC. The economic burden of adults with major depressive disorder in the United States (2005 and 2010). J Clin Psychiatry. 2015;76:155-62. 
Guida F, Boccella S, Belardo C, lannotta M, Piscitelli F, De Filippis F, et al. Altered gut microbiota and endocannabinoid system tone in vitamin $D$ deficiency-mediated chronic pain. Brain, Behavior, and Immunity. 2019.

Gur TL, Shay L, Palkar AV, Fisher S, Varaljay VA, Dowd S, et al. Prenatal stress affects placental cytokines and neurotrophins, commensal microbes, and anxiety-like behavior in adult female offspring. Brain, Behavior, and Immunity. 2017;64:50-8.

Heijtz RD, Wang S, Anuar F, Qian Y, Björkholm B, Samuelsson A, et al. Normal gut microbiota modulates brain development and behavior. Proceedings of the National Academy of Sciences. 2011;108:3047-52. Hemmings SMJ, Malan-Muller S, van den Heuvel LL, Demmitt BA, Stanislawski MA, Smith DG, et al. The Microbiome in Posttraumatic Stress Disorder and Trauma-Exposed Controls: An Exploratory Study. Psychosomatic medicine. 2017;79:936-46.

Hill DA, Artis D. Intestinal bacteria and the regulation of immune cell homeostasis. Annual review of immunology. 2010;28:623-67.

Hoban AE, Stilling RM, G MM, Moloney RD, Shanahan F, Dinan TG, et al. Microbial regulation of microRNA expression in the amygdala and prefrontal cortex. Microbiome. 2017;5:102.

Hoban AE, Stilling RM, Moloney G, Shanahan F, Dinan TG, Clarke G, et al. The microbiome regulates amygdala-dependent fear recall. Molecular Psychiatry. 2018;23:1134-44.

Hoban AE, Stilling RM, Ryan FJ, Shanahan F, Dinan TG, Claesson MJ, et al. Regulation of prefrontal cortex myelination by the microbiota. Transl Psychiatry. 2016;6:e774-e.

Hoebel BG. Neuroscience and Appetitive Behavior Research: 25 Years. Appetite. 1997;29:119-33.

Holmes E, Kinross J, Gibson GR, Burcelin R, Jia W, Pettersson S, et al. Therapeutic Modulation of Microbiota-Host Metabolic Interactions. Science Translational Medicine. 2012;4:137rv6-rv6.

Holzer P. Efferent-like roles of afferent neurons in the gut: Blood flow regulation and tissue protection. Autonomic neuroscience : basic \& clinical. 2006a;125:70-5.

Holzer P. Efferent-like roles of afferent neurons in the gut: Blood flow regulation and tissue protection. Auton Neurosci. 2006b;125:70-5.

Hsiao EY, McBride SW, Hsien S, Sharon G, Hyde ER, McCue T, et al. Microbiota modulate behavioral and physiological abnormalities associated with neurodevelopmental disorders. Cell. 2013;155:1451-63. Jakobshagen K, Buch T, Schwierzeck V, Utermohlen O, Chun E, Garrett WS, et al. Nature neuroscience. Jašarević $E$, Rodgers $A B$, Bale TL. A novel role for maternal stress and microbial transmission in early life programming and neurodevelopment. Neurobiology of Stress. 2015;1:81-8.

Jeffery IB, Quigley EMM, Öhman L, Simrén M, O'Toole PW. The microbiota link to irritable bowel syndrome. Gut Microbes. 2012;3:572-6.

Jiang $\mathrm{H}-\mathrm{y}$, Ling $\mathrm{Z}$, Zhang $\mathrm{Y}$, Mao $\mathrm{H}, \mathrm{Ma} \mathrm{Z}$, Yin $\mathrm{Y}$, et al. Altered fecal microbiota composition in patients with major depressive disorder. Brain Behavior and Immunity. 2015a;37.

Jiang $\mathrm{H}$, Ling Z, Zhang Y, Mao H, Ma Z, Yin Y, et al. Altered fecal microbiota composition in patients with major depressive disorder. Brain Behav Immun. 2015b;48:186-94.

Jokela M, Virtanen M, Batty GD, Kivimäki M. Inflammation and Specific Symptoms of Depression. JAMA Psychiatry. 2016;73:87-8.

Kelly JR, Borre Y, C OB, Patterson E, El Aidy S, Deane J, et al. Transferring the blues: Depressionassociated gut microbiota induces neurobehavioural changes in the rat. Journal of psychiatric research. 2016;82:109-18.

Kelly JR, Keane VO, Cryan JF, Clarke G, Dinan TG. Mood and Microbes: Gut to Brain Communication in Depression. Gastroenterology clinics of North America. 2019;48:389-405.

Kelly JR, Kennedy PJ, Cryan JF, Dinan TG, Clarke G, Hyland NP. Breaking down the barriers: the gut microbiome, intestinal permeability and stress-related psychiatric disorders. Front Cell Neurosci. 2015;9:392-. 
Kennedy PJ, Clarke G, O'Neill A, Groeger JA, Quigley EMM, Shanahan F, et al. Cognitive performance in irritable bowel syndrome: evidence of a stress-related impairment in visuospatial memory. Psychological medicine. 2014a;44:1553-66.

Kennedy PJ, Cryan JF, Dinan TG, Clarke G. Irritable bowel syndrome: a microbiome-gut-brain axis disorder? World J Gastroenterol. 2014b;20:14105-25.

Kennedy PJ, Cryan JF, Dinan TG, Clarke G. Kynurenine pathway metabolism and the microbiota-gut-brain axis. Neuropharmacology. 2017;112:399-412.

Kennedy PJ, Cryan JF, Quigley EMM, Dinan TG, Clarke G. A sustained hypothalamic-pituitary-adrenal axis response to acute psychosocial stress in irritable bowel syndrome. Psychological Medicine. 2014c;44:3123-34.

Kim H-N, Yun Y, Ryu S, Chang Y, Kwon M-J, Cho J, et al. Correlation between gut microbiota and personality in adults: A cross-sectional study. Brain, Behavior, and Immunity. 2018;69:374-85. Kiraly DD. Gut microbes regulate neurons to help mice forget their fear. Nature. 2019;574:488-9. Kiraly DD, Walker DM, Calipari ES, Labonte B, Issler O, Pena CJ, et al. Alterations of the Host Microbiome Affect Behavioral Responses to Cocaine. Scientific reports. 2016;6:35455-.

Konstantinov SR, Peppelenbosch MP. Fecal Microbiota Transfer May Increase Irritable Bowel Syndrome and Inflammatory Bowel Diseases\&\#x2013;Associated Bacteria. Gastroenterology. 2013;144:e19-e20.

Kurokawa S, Kishimoto T, Mizuno S, Masaoka T, Naganuma M, Liang K-c, et al. The effect of fecal microbiota transplantation on psychiatric symptoms among patients with irritable bowel syndrome, functional diarrhea and functional constipation: An open-label observational study. Journal of affective disorders. 2018;235:506-12.

Kuti D, Winkler Z, Horváth K, Juhász B, Paholcsek M, Stágel A, et al. Gastrointestinal (non-systemic) antibiotic rifaximin differentially affects chronic stress-induced changes in colon microbiome and gut permeability without effect on behavior. Brain, Behavior, and Immunity. 2020;84:218-28.

Lemon KP, Armitage GC, Relman DA, Fischbach MA. Microbiota-Targeted Therapies: An Ecological Perspective. Science Translational Medicine. 2012;4:137rv5-rv5.

Leonard BE. The HPA and immune axes in stress: The involvement of the serotonergic system. European Psychiatry. 2005;20:S302-S6.

Li $N$, Wang $Q$, Wang $Y$, Sun $A$, Lin $Y$, Jin $Y$, et al. Fecal microbiota transplantation from chronic unpredictable mild stress mice donors affects anxiety-like and depression-like behavior in recipient mice via the gut microbiota-inflammation-brain axis. Stress (Amsterdam, Netherlands). 2019;22:592-602.

Li Q, Zhou JM. The microbiota-gut-brain axis and its potential therapeutic role in autism spectrum disorder. Neuroscience. 2016;324:131-9.

Li W, Dowd SE, Scurlock B, Acosta-Martinez V, Lyte M. Memory and learning behavior in mice is temporally associated with diet-induced alterations in gut bacteria. Physiol Behav. 2009;96:557-67.

Liu S, Mi W-L, Li Q, Zhang M-T, Han P, Hu S, et al. Spinal IL-33/ST2 Signaling Contributes to Neuropathic Pain via Neuronal CaMKII-CREB and Astroglial JAK2-STAT3 Cascades in Mice. Anesthesiology: The Journal of the American Society of Anesthesiologists. 2015;123:1154-69.

Long-Smith C, O'Riordan KJ, Clarke G, Stanton C, Dinan TG, Cryan JF. Microbiota-Gut-Brain Axis: New Therapeutic Opportunities. Annual Review of Pharmacology and Toxicology. 2020;60:477-502.

Lu J, Synowiec S, Lu L, Yu Y, Bretherick T, Takada S, et al. Microbiota influence the development of the brain and behaviors in C57BL/6J mice. PLoS One. 2018;13:e0201829-e.

Lucassen PJ, Pruessner J, Sousa N, Almeida OFX, Van Dam AM, Rajkowska G, et al. Neuropathology of stress. Acta Neuropathol. 2014;127:109-35.

Luczynski P, Whelan SO, O'Sullivan C, Clarke G, Shanahan F, Dinan TG, et al. Adult microbiota-deficient mice have distinct dendritic morphological changes: differential effects in the amygdala and hippocampus. European Journal of Neuroscience. 2016;44:2654-66. 
Lyte M, Li W, Opitz N, Gaykema R, Goehler L. Induction of anxiety-like behavior in mice during the initial stages of infection with the agent of murine colonic hyperplasia Citrobacter rodentium. Physiology \& behavior. 2006;89:350-7. Mack MR, Kim BS. The Itch\&\#x2013;Scratch Cycle: A Neuroimmune Perspective. Trends in Immunology. 2018;39:980-91. enhanced severity of Citrobacter rodentium infection. Infect Immun. 2013;81:3253-63.

Maes $M$, Kubera $M$, Leunis JC. The gut-brain barrier in major depression: intestinal mucosal dysfunction with an increased translocation of LPS from gram negative enterobacteria (leaky gut) plays a role in the inflammatory pathophysiology of depression. Neuro endocrinology letters. 2008;29:117-24.

Mardinoglu A, Shoaie S, Bergentall M, Ghaffari P, Zhang C, Larsson E, et al. The gut microbiota modulates host amino acid and glutathione metabolism in mice. Mol Syst Biol. 2015;11:834-.

Maren S, Phan KL, Liberzon I. The contextual brain: implications for fear conditioning, extinction and psychopathology. Nat Rev Neurosci. 2013;14:417-28.

Marques T, Patterson E, Wall R, O'Sullivan O, Fitzgerald GF, Cotter P, et al. Influence of GABA and GABAproducing Lactobacillus brevis DPC 6108 on the development of diabetes in a streptozotocin rat model. Beneficial microbes. 2016;7:1-12.

Maslowski KM, Vieira AT, Ng A, Kranich J, Sierro F, Yu D, et al. Regulation of inflammatory responses by gut microbiota and chemoattractant receptor GPR43. Nature. 2009;461:1282-6.

Matsumoto M, Kibe R, Ooga T, Aiba Y, Sawaki E, Koga Y, et al. Cerebral low-molecular metabolites influenced by intestinal microbiota: a pilot study. Front Syst Neurosci. 2013;7:9-.

Matthews DM, Jenks SM. Ingestion of Mycobacterium vaccae decreases anxiety-related behavior and improves learning in mice. Behavioural processes. 2013;96:27-35.

Mayer EA. Gut feelings: the emerging biology of gut-brain communication. Nature reviews Neuroscience. 2011;12:453-66.

Mayer EA, Knight R, Mazmanian SK, Cryan JF, Tillisch K. Gut microbes and the brain: paradigm shift in neuroscience. J Neurosci. 2014;34:15490-6.

Mayer EA, Tillisch K, Gupta A. Gut/brain axis and the microbiota. The Journal of clinical investigation. 2015;125:926-38.

Maynard CL, Elson CO, Hatton RD, Weaver CT. Reciprocal interactions of the intestinal microbiota and immune system. Nature. 2012;489:231-41.

McKernan DP, Fitzgerald P, Dinan TG, Cryan JF. The probiotic Bifidobacterium infantis 35624 displays visceral antinociceptive effects in the rat. Neurogastroenterology \& Motility. 2010;22:1029-e268.

Messaoudi M, Lalonde R, Violle N, Javelot H, Desor D, Nejdi A, et al. Assessment of psychotropic-like properties of a probiotic formulation (Lactobacillus helveticus R0052 and Bifidobacterium longum R0175) in rats and human subjects. British Journal of Nutrition. 2010;105:755-64.

Messaoudi M, Lalonde R, Violle N, Javelot H, Desor D, Nejdi A, et al. Assessment of psychotropic-like properties of a probiotic formulation (Lactobacillus helveticus R0052 and Bifidobacterium longum R0175) in rats and human subjects. The British journal of nutrition. 2011;105:755-64.

Mohammadi AA, Jazayeri S, Khosravi-Darani K, Solati Z, Mohammadpour N, Asemi Z, et al. Effects of Probiotics on Biomarkers of Oxidative Stress and Inflammatory Factors in Petrochemical Workers: A Randomized, Double-blind, Placebo-controlled Trial. Int J Prev Med. 2015;6:82-.

Moloney RD, Desbonnet L, Clarke G, Dinan TG, Cryan JF. The microbiome: stress, health and disease. Mammalian Genome. 2014;25:49-74.

Moloney RD, Johnson AC, O'Mahony SM, Dinan TG, Greenwood-Van Meerveld B, Cryan JF. Stress and the Microbiota-Gut-Brain Axis in Visceral Pain: Relevance to Irritable Bowel Syndrome. CNS Neurosci Ther. 2016;22:102-17. 
Moloney RD, O'Mahony SM, Dinan TG, Cryan JF. Stress-induced visceral pain: toward animal models of irritable-bowel syndrome and associated comorbidities. Front Psychiatry. 2015;6:15-.

Musso G, Gambino R, Cassader M. Interactions Between Gut Microbiota and Host Metabolism Predisposing to Obesity and Diabetes. Annual Review of Medicine. 2011;62:361-80.

Neufeld K-AM, Kang N, Bienenstock J, Foster JA. Effects of intestinal microbiota on anxiety-like behavior. Commun Integr Biol. 2011;4:492-4.

Nicholson JK, Holmes E, Kinross J, Burcelin R, Gibson G, Jia W, et al. Host-gut microbiota metabolic interactions. Science (New York, NY). 2012;336:1262-7.

Nøhr M, Egerod K, Christiansen S, Gille A, Offermanns S, Schwartz T, et al. Expression of the short chain fatty acid receptor GPR41/FFAR3 in autonomic and somatic sensory ganglia. Neuroscience. 2015;290.

O'Mahony S, Felice V, Nally K, Savignac H, Claesson M, Scully P, et al. Disturbance of the Gut microbiota in early-life selectively affects visceral pain in adulthood without impacting cognitive or anxiety-related behaviors in male rats. Neuroscience. 2014;277.

O'Mahony SM, Clarke G, Borre YE, Dinan TG, Cryan JF. Serotonin, tryptophan metabolism and the braingut-microbiome axis. Behavioural brain research. 2015;277:32-48.

Ohland CL, Kish L, Bell H, Thiesen A, Hotte N, Pankiv E, et al. Effects of Lactobacillus helveticus on murine behavior are dependent on diet and genotype and correlate with alterations in the gut microbiome. Psychoneuroendocrinology. 2013;38:1738-47.

Oliveros E, Ramirez M, Vazquez E, Barranco A, Gruart A, Delgado-Garcia JM, et al. Oral supplementation of 2'-fucosyllactose during lactation improves memory and learning in rats. J Nutr Biochem. 2016;31:207.

Overduin J, Schoterman MHC, Calame W, Schonewille AJ, Ten Bruggencate SJM. Dietary galactooligosaccharides and calcium: effects on energy intake, fat-pad weight and satiety-related, gastrointestinal hormones in rats. British Journal of Nutrition. 2012;109:1338-48.

Pan J-X, Deng F-L, Zeng B-H, Zheng P, Liang W-W, Yin B-M, et al. Absence of gut microbiota during early life affects anxiolytic Behaviors and monoamine neurotransmitters system in the hippocampal of mice. Journal of the Neurological Sciences. 2019;400:160-8.

Park AJ, Collins J, Blennerhassett PA, Ghia JE, Verdu EF, Bercik P, et al. Altered colonic function and microbiota profile in a mouse model of chronic depression. Neurogastroenterol Motil. 2013;25:733e575.

Penders J, Vink C, Driessen C, London N, Thijs C, Stobberingh EE. Quantification of Bifidobacterium spp., Escherichia coli and Clostridium difficile in faecal samples of breast-fed and formula-fed infants by realtime PCR. FEMS Microbiology Letters. 2005;243:141-7.

Pérez-Escuredo J, Van Hée VF, Sboarina M, Falces J, Payen VL, Pellerin L, et al. Monocarboxylate transporters in the brain and in cancer. Biochim Biophys Acta. 2016;1863:2481-97.

Petra Al, Panagiotidou S, Hatziagelaki E, Stewart JM, Conti P, Theoharides TC. Gut-Microbiota-Brain Axis and Its Effect on Neuropsychiatric Disorders With Suspected Immune Dysregulation. Clinical therapeutics. 2015a;37:984-95.

Petra Al, Panagiotidou S, Hatziagelaki E, Stewart JM, Conti P, Theoharides TC. Gut-Microbiota-Brain Axis and Its Effect on Neuropsychiatric Disorders With Suspected Immune Dysregulation. Clinical therapeutics. 2015b;37:984-95.

Pierre K, Pellerin L. Monocarboxylate transporters in the central nervous system: distribution, regulation and function. Journal of neurochemistry. 2005;94:1-14.

Prenderville JA, Kennedy PJ, Dinan TG, Cryan JF. Adding fuel to the fire: the impact of stress on the ageing brain. Trends in neurosciences. 2015;38:13-25.

Rankin A, O'Donavon C, Madigan SM, O'Sullivan O, Cotter PD. 'Microbes in sport' - The potential role of the gut microbiota in athlete health and performance. British Journal of Sports Medicine. 2017;51:698-9. 
Reber SO, Siebler PH, Donner NC, Morton JT, Smith DG, Kopelman JM, et al. Immunization with a heatkilled preparation of the environmental bacterium Mycobacterium vaccae promotes stress resilience in mice. Proceedings of the National Academy of Sciences of the United States of America. 2016;113:E3130-E9.

Reigstad CS, Salmonson CE, Rainey JF, 3rd, Szurszewski JH, Linden DR, Sonnenburg JL, et al. Gut microbes promote colonic serotonin production through an effect of short-chain fatty acids on enterochromaffin cells. FASEB J. 2015;29:1395-403.

Rieder R, Wisniewski PJ, Alderman BL, Campbell SC. Microbes and mental health: A review. Brain, Behavior, and Immunity. 2017;66:9-17.

Ritchie ML, Romanuk TN. A meta-analysis of probiotic efficacy for gastrointestinal diseases. PloS one. 2012;7:e34938.

Roshchina VV. New Trends and Perspectives in the Evolution of Neurotransmitters in Microbial, Plant, and Animal Cells. In: Lyte M, editor. Microbial Endocrinology: Interkingdom Signaling in Infectious Disease and Health. Cham: Springer International Publishing; 2016. p. 25-77.

Round JL, Mazmanian SK. The gut microbiota shapes intestinal immune responses during health and disease. Nature reviews Immunology. 2009;9:313-23.

Sampson TR, Mazmanian SK. Control of brain development, function, and behavior by the microbiome. Cell host \& microbe. 2015;17:565-76.

Sandhu KV, Sherwin E, Schellekens H, Stanton C, Dinan TG, Cryan JF. Feeding the microbiota-gut-brain axis: diet, microbiome, and neuropsychiatry. Translational Research. 2017;179:223-44.

Sanger GJ, Lee K. Hormones of the gut-brain axis as targets for the treatment of upper gastrointestinal disorders. Nature Reviews Drug Discovery. 2008;7:241-54.

Savignac HM, Corona G, Mills H, Chen L, Spencer JPE, Tzortzis G, et al. Prebiotic feeding elevates central brain derived neurotrophic factor, N-methyl-D-aspartate receptor subunits and D-serine. Neurochemistry international. 2013;63:756-64.

Savignac HM, Kiely B, Dinan TG, Cryan JF. Bifidobacteria exert strain-specific effects on stress-related behavior and physiology in BALB/c mice. Neurogastroenterol Motil. 2014;26:1615-27.

Schellekens H, Finger BC, Dinan TG, Cryan JF. Ghrelin signalling and obesity: At the interface of stress, mood and food reward. Pharmacology \& Therapeutics. 2012;135:316-26.

Schiepers OJ, Wichers MC, Maes M. Cytokines and major depression. Progress in neuropsychopharmacology \& biological psychiatry. 2005;29:201-17.

Schmidt EKA, Torres-Espin A, Raposo PJF, Madsen KL, Kigerl KA, Popovich PG, et al. Fecal transplant prevents gut dysbiosis and anxiety-like behaviour after spinal cord injury in rats. PLoS One. 2020;15:e0226128.

Schmidt K, Cowen PJ, Harmer CJ, Tzortzis G, Errington S, Burnet PWJ. Prebiotic intake reduces the waking cortisol response and alters emotional bias in healthy volunteers. Psychopharmacology (Berl). 2015;232:1793-801.

Scott KA, Ida M, Peterson VL, Prenderville JA, Moloney GM, Izumo T, et al. Revisiting Metchnikoff: Agerelated alterations in microbiota-gut-brain axis in the mouse. Brain, Behavior, and Immunity. 2017;65:20-32.

Sherwin E, Bordenstein SR, Quinn JL, Dinan TG, Cryan JF. Microbiota and the social brain. Science. 2019;366:eaar2016.

Siebler PH, Heinze JD, Kienzle DM, Hale MW, Lukkes JL, Donner NC, et al. Acute Administration of the Nonpathogenic, Saprophytic Bacterium, Mycobacterium vaccae, Induces Activation of Serotonergic Neurons in the Dorsal Raphe Nucleus and Antidepressant-Like Behavior in Association with Mild Hypothermia. 2018;38:289-304. 
Snoek SA, Verstege MI, Boeckxstaens GE, van den Wijngaard RM, de Jonge WJ. The enteric nervous system as a regulator of intestinal epithelial barrier function in health and disease. Expert review of gastroenterology \& hepatology. 2010;4:637-51.

Steenbergen L, Sellaro R, van Hemert S, Bosch JA, Colzato LS. A randomized controlled trial to test the effect of multispecies probiotics on cognitive reactivity to sad mood. Brain Behav Immun. 2015;48:25864.

Stevens BR, Roesch L, Thiago P, Russell JT, Pepine CJ, Holbert RC, et al. Depression phenotype identified by using single nucleotide exact amplicon sequence variants of the human gut microbiome. Mol Psychiatry. 2020.

Stilling RM, Dinan TG, Cryan JF. The brain's Geppetto-microbes as puppeteers of neural function and behaviour? Journal of neurovirology. 2016a;22:14-21.

Stilling RM, Moloney GM. Social interaction-induced activation of RNA splicing in the amygdala of microbiome-deficient mice. 2018;7.

Stilling RM, Ryan FJ, Hoban AE, Shanahan F, Clarke G, Claesson MJ, et al. Microbes \& neurodevelopment - Absence of microbiota during early life increases activity-related transcriptional pathways in the amygdala. Brain, Behavior, and Immunity. 2015;50:209-20.

Stilling RM, van de Wouw M, Clarke G, Stanton C, Dinan TG, Cryan JF. The neuropharmacology of butyrate: The bread and butter of the microbiota-gut-brain axis? Neurochemistry international. 2016b;99:110-32.

Sudo N, Chida Y, Aiba Y, Sonoda J, Oyama N, Yu X-N, et al. Postnatal microbial colonization programs the hypothalamic-pituitary-adrenal system for stress response in mice. J Physiol. 2004;558:263-75.

Sun J, Wang F, Hong G, Pang M, Xu H, Li H, et al. Antidepressant-like effects of sodium butyrate and its possible mechanisms of action in mice exposed to chronic unpredictable mild stress. Neuroscience letters. 2016;618:159-66.

Sun $Y$, Zhang $M$, Chen C-C, Gillilland M, 3rd, Sun X, El-Zaatari M, et al. Stress-induced corticotropinreleasing hormone-mediated NLRP6 inflammasome inhibition and transmissible enteritis in mice. Gastroenterology. 2013;144:1478-87.e14878.

Sundman MH, Chen NK, Subbian V, Chou YH. The bidirectional gut-brain-microbiota axis as a potential nexus between traumatic brain injury, inflammation, and disease. Brain Behav Immun. 2017;66:31-44.

Taj A, Jamil N. Bioconversion of Tyrosine and Tryptophan Derived Biogenic Amines by Neuropathogenic Bacteria. Biomolecules. 2018;8:10.

Thion MS, Low D, Silvin A, Chen J, Grisel P, Schulte-Schrepping J, et al. Microbiome Influences Prenatal and Adult Microglia in a Sex-Specific Manner. Cell. 2018;172:500-16.e16.

Tillisch K, Labus J, Kilpatrick L, Jiang Z, Stains J, Ebrat B, et al. Consumption of fermented milk product with probiotic modulates brain activity. Gastroenterology. 2013;144:1394-401.e14014.

Tremaroli V, Backhed F. Functional interactions between the gut microbiota and host metabolism. Nature. 2012;489:242-9.

Tsigos C, Chrousos GP. Hypothalamic-pituitary-adrenal axis, neuroendocrine factors and stress. Journal of Psychosomatic Research. 2002;53:865-71.

van de Wouw M, Lyte JM, Boehme M, Sichetti M, Moloney G, Goodson MS, et al. The role of the microbiota in acute stress-induced myeloid immune cell trafficking. Brain, Behavior, and Immunity. 2020;84:209-17.

Vinolo MAR, Rodrigues HG, Nachbar RT, Curi R. Regulation of inflammation by short chain fatty acids. Nutrients. 2011;3:858-76. Vuong HE, Yano JM, Fung TC, Hsiao EY. The Microbiome and Host Behavior. Annual review of neuroscience. 2017;40:21-49.

Wang Y, Kasper LH. The role of microbiome in central nervous system disorders. Brain Behav Immun. 2014;38:1-12. 
Wiest R, Garcia-Tsao G. Bacterial translocation (BT) in cirrhosis. Hepatology. 2005;41:422-33.

Williams BB, Van Benschoten AH, Cimermancic P, Donia MS, Zimmermann M, Taketani M, et al. Discovery and characterization of gut microbiota decarboxylases that can produce the neurotransmitter tryptamine. Cell host \& microbe. 2014;16:495-503.

Wong ML, Inserra A, Lewis MD, Mastronardi CA, Leong L, Choo J, et al. Inflammasome signaling affects anxiety- and depressive-like behavior and gut microbiome composition. Molecular psychiatry. 2016;21:797-805.

World Health O. Depression and other common mental disorders: global health estimates. Geneva: World Health Organization; 2017.

Yano JM, Yu K, Donaldson GP, Shastri GG, Ann P, Ma L, et al. Indigenous bacteria from the gut microbiota regulate host serotonin biosynthesis. Cell. 2015;161:264-76.

Yarandi SS, Peterson DA, Treisman GJ, Moran TH, Pasricha PJ. Modulatory Effects of Gut Microbiota on the Central Nervous System: How Gut Could Play a Role in Neuropsychiatric Health and Diseases. J Neurogastroenterol Motil. 2016;22:201-12.

Yong SJ, Tong T, Chew J, Lim WL. Antidepressive Mechanisms of Probiotics and Their Therapeutic Potential. Front Neurosci. 2020;13:1361-.

Yu M, Jia H, Zhou C, Yang Y, Zhao Y, Yang M, et al. Variations in gut microbiota and fecal metabolic phenotype associated with depression by $16 \mathrm{~S}$ rRNA gene sequencing and LC/MS-based metabolomics. Journal of Pharmaceutical and Biomedical Analysis. 2017;138:231-9.

Zen M, Canova M, Campana C, Bettio S, Nalotto L, Rampudda M, et al. The kaleidoscope of glucorticoid effects on immune system. Autoimmunity reviews. 2011;10:305-10.

Zhan Y, Paolicelli RC, Sforazzini F, Weinhard L, Bolasco G, Pagani F, et al. Deficient neuron-microglia signaling results in impaired functional brain connectivity and social behavior. Nature neuroscience. 2014;17:400-6.

Zheng P, Zeng B, Zhou C, Liu M, Fang Z, Xu X, et al. Gut microbiome remodeling induces depressive-like behaviors through a pathway mediated by the host's metabolism. Mol Psychiatry. 2016;21:786-96.

Zhu F, Guo R, Wang W, Ju Y, Wang Q. Transplantation of microbiota from drug-free patients with schizophrenia causes schizophrenia-like abnormal behaviors and dysregulated kynurenine metabolism in mice. 2019.

Zhuang L, Chen H, Zhang S, Zhuang J, Li Q, Feng Z. Intestinal Microbiota in Early Life and Its Implications on Childhood Health. Genomics, proteomics \& bioinformatics. 2019;17:13-25.

Zou N, Lv H, Li J, Yang N, Xue H, Zhu J, et al. Changes in brain G proteins and colonic sympathetic neural signaling in chronic-acute combined stress rat model of irritable bowel syndrome (IBS). Translational research : the journal of laboratory and clinical medicine. 2009;152:283-9. 